\title{
Analysis of Roof Deformation Mechanism and Control Measures with Roof Cutting and Pressure Releasing in Gob-Side Entry Retaining
}

\author{
Bing-Jun Sun $\mathbb{D}^{1,2}$ Xin-Zhu Hua, ${ }^{1,2}$ Yan Zhang, ${ }^{3}$ Jiadi Yin, ${ }^{1,2}$ Kai He, ${ }^{1,2}$ \\ Chengxing Zhao $\left(\mathbb{D},{ }^{1,2}\right.$ and Yingfu $\mathrm{Li}^{1,2}$ \\ ${ }^{1}$ State Key Laboratory of Deep Coal Mine Mining Response and Disaster Prevention and Control, \\ Anhui University of Science and Technology, Huainan 232001, China \\ ${ }^{2}$ Anhui University of Science and Technology, Key Laboratory of Coal Mine Safety and Efficient Mining, Ministry of Education, \\ Huainan 232001, China \\ ${ }^{3}$ State Key Laboratory of Deep Geotechnical Mechanics and Underground Engineering, \\ China University of Mining and Technology, Xuzhou, Jiangsu 221116, China
}

Correspondence should be addressed to Bing-Jun Sun; 2018200094@aust.edu.cn

Received 2 November 2020; Revised 2 December 2020; Accepted 9 January 2021; Published 29 January 2021

Academic Editor: Yuantian Sun

Copyright (C) 2021 Bing-Jun Sun et al. This is an open access article distributed under the Creative Commons Attribution License, which permits unrestricted use, distribution, and reproduction in any medium, provided the original work is properly cited.

\begin{abstract}
The mechanical model of the basic roof fracture structure is established on the basis of key block theory to study the roof breaking mechanism of gob-side entry retaining under roof cutting and pressure relief, and the analytical formula of roof support resistance is derived when the key block of the basic roof is stable. The influence of roof cutting angle and cutting height on roof support resistance is also analyzed. Determining the cutting seam parameters of the retained roadway roof is necessary to identify the support resistance of the roadway roof due to the correlation between the roof cutting parameters and the support resistance. Taking the II 632 haulage drift of the Hengyuan coal mine as the engineering background, FLAC3D numerical simulation is used in this paper to analyze the influence of different roof cutting angles and cutting heights on the surrounding rock structure evolution of retained roadways. Results show that the roof cutting angle and cutting height respond to the support resistance of the retained roadway roof, and the support resistance required by the roof increases with the roof cutting angle and cutting height. This condition ensures that the side roof of the gob can be cut off smoothly, and the support resistance required by the roof of retained roadways is within a reasonable range. Through theoretical and numerical simulation analysis, the reasonable roof cutting height of II 632 haulage drift is $8 \mathrm{~m}$ and the roof cutting angle is $15^{\circ}$. The theoretical analysis and numerical simulation results reveal that the required support resistance to maintain the stability of the roadway roof is $0.38 \mathrm{MPa}$. The supporting scheme of the roof of the II 632 haulage drift in the Hengyuan coal mine is then designed. Finally, the field industrial test is used for verification. The borehole imaging results show that the overall line of the retained roadway roof is small based on the description of field monitoring results. The deformation of the surrounding rock surface of the retained roadway is less than $100 \mathrm{~mm}$, and the roadway is $40 \mathrm{~m}$ from the lagging working face. The deformation rate of surrounding rock decreases with the increase in distance from the working face. The integrity of the retained roadway roof is good, and the deformation of the surrounding rock is effectively controlled.
\end{abstract}

\section{Introduction}

Owing to the increasing contradiction between the daily reduction of coal resources and energy demand, the roof cutting and pressure relief technology in gob-side entry retaining can effectively reduce the waste of coal resources [1-4]. However, the roof deformation of the retained roadway is serious, and the roadway support difficulty has become a new problem. Therefore, many local and foreign scholars have conducted a considerable amount of research. 
Reference [5] established the structural model of the retained roadway roof and determined the design of the retained roadway roof in the excavation process. This design was successfully applied in the Halagou coal mine. Considering the numerical simulation method and laboratory experiment in [6], directional blasting can reduce roof damage of the retained roadway in the process of roof cutting and pressure relief. References [7,8] discussed the stress distribution range of the retained roadway roof by establishing the mechanical structure model and effectively controlled the deformation of the retained roadway roof by using the constant resistance anchor cable. Reference [9] analyzed the stress distribution characteristics of retained roadway roof in medium-thick coal seam by the mechanical model and found that the goaf gangue has a good supporting effect on the retained roadway roof with a decrease in cantilever beam length. Reference [10] analyzed the application of the new telescopic energy absorption support system on the surrounding rock of the retained roadway by the numerical simulation method and found that the new support system is conducive to maintain the stability of the retained roadway roof compared with the traditional support method. In [11], the theoretical and analytical formulas of roof deformation of the retained roadway are obtained by energy theory and verified by field measurement. Reference [12] theoretically analyzed the broken position of the retained roadway roof and concluded through the assessment of UDEC numerical simulation software that the fracture of the retained roadway roof on one side of the goaf is conducive to the roadway stability. In [13], the influence of working face pressure in the roof cutting and pressure relief technology and the conventional mining method was examined by field monitoring and numerical simulation. This reference concluded that the roof cutting and pressure relief technology can produce a low-stress area in the roadway. Reference [14] obtained the deformation characteristics of gob-side entry retaining roadway under different stages of roof cutting and pressure relief through similar physical simulation experiments. The results show that the surrounding rock behind the working face reaches a stable state after the working face is excavated for $20 \mathrm{~m}$, and the surrounding rock pressure of roadway is effectively relieved through roof presplitting and seam cutting. The paper introduces the partition control technology of the roadway retaining based on the analysis of roof rock movement characteristics of gob-side entry retaining in [15]. Through the analysis of the support modes in different areas in the gob-side entry retaining, the mining mode requires that the mining roadway should be driven in advance and the protective coal pillar should be reserved in the conventional mining process. Reference [16] adopted the combined support technology of constant resistance anchor cable and single hydraulic prop to solve the serious roadway deformation problem in the roof cutting and pressure relief technology of 2422 working face in Baijiao coal mine effectively.

The research results of many scholars revealed that the roadway roof with gob-side entry retaining can effectively solve the roadway deformation problem through the roof cutting and pressure relief technology despite the broken roof of the retained roadway or its short cantilever beam structure, which is closely related to the roof cutting angle and height. Therefore, the determination of the key parameters of roof cutting seam parameters is the key to the gob-side entry retaining technology. Reference [17] studied the key parameters of roadway roof blasting in the process of roof cutting and pressure relief by mathematical analysis and optimized the process of roof blasting design for retaining roadway. The analysis of the stress dynamic evolution law of the retained roadway roof in Reference [18] showed that the fracture position of the retained roadway roof is related to the key parameters of roof cutting. Reference [19] obtained the angle and height of roof cutting through physical experiments and successfully cut the goaf roof. The research methods of theoretical analysis, numerical simulation, and field measurement are used in Reference [20,21]. The reasonable range of roof cutting height and angle in the roof cutting and pressure relief technology is determined and successfully applied in many coal mines, such as Chengjiao coal mine.

The above research results revealed that the roof cutting and pressure relief technology can cut off the connection between the roof of the retained roadway and that on the goaf side. However, most of the previous studies focused on the influence of roof cutting seam parameters on the inner area of the solid coal side of the retained roadway, while the research on the influence of the roof cutting seam parameters on the roof support of the retained roadway is limited. Based on previous studies, this paper analyzes the fracture principle of roof strata in gob-side entry retaining and pressure relief roadway roof. The influence of different roof cutting angles and heights on the roof support resistance of retaining roadway is also studied. The stress distribution characteristics of surrounding rock under different roof cutting seam parameters are analyzed by FLAC3D numerical simulation software. The reasonable values of roof cutting height and angle of II 632 haulage drift in the Hengyuan coal mine are determined. Finally, the corresponding support scheme is proposed in accordance with the actual situation of II 632 haulage drift in the Hengyuan coal mine. The research results provide a certain reference value for the design of roof support parameters of gob-side entry retaining under roof cutting and pressure relief.

\section{Roof Breaking Mechanism of Gob-Side Entry Retaining with Roof Cutting and Pressure Relief}

The research results of many scholars on the structural characteristics of roof strata of mining roadway [22, 23] show the rapid collapse of the strata in the goaf behind the support with the advancement of the mining face. The overhanging area above the retained roadway becomes increasingly large, thus allowing the goaf to form an $\mathrm{O}-\mathrm{X}$ fracture structure. With the continuous advancement of the coal mining face, the location with a certain area of overhanging behind the support will break again under the action of gravity, thus resulting in periodic weighting behaviors of goaf. 
In the gob-side entry retaining technology of roof cutting and pressure relief, one side of the roadway is solid coal, and the other side is the rock block caving area in the goaf. The key block B structure will be formed in the rock section of the retained roadway roof. The immediate roof is the most important factor affecting the stability of retained roadways. This paper mainly studies the fracture form of the key structure of the roadway roof and the influence of the roadway support resistance on the stability of the retained roadway. The key block $\mathrm{B}$ is simplified as a triangular structure model to facilitate analysis. Figure 1 shows the space top view, where $\alpha$ is the angle between the space triangle and the collapse distance, ${ }^{\circ} ; l$ is the interval of periodic weighting, $\mathrm{m} ; L_{d}$ is the horizontal distance of key block $\mathrm{B}, \mathrm{m}$.

\section{Key Block Structure of Retaining Roadway Roof}

After the retained roadway roof is fractured, the roadway roof will form a fractured structure as shown in Figure 2. The key block A above the solid coal side forms an articulated structure with the key block B above the roadway and the key block $\mathrm{C}$ above the goaf. Among these key blocks, key block B breaks in the interior of the roadway solid coal, and the fracture location is at the interface of the elastic-plastic zone on the side of the roadway solid coal. The key block B revolves and sinks around the fracture position in the solid coal side. In the process of sinking, the key block B contacts with and compacts the caving rock block in the goaf by its gravity. The key block B finally stabilizes due to the supporting force of the rock blocks in the goaf. At this time, the key block B forms a stable load-bearing structure, which plays a protective role in retaining roadways. Among them, $f_{s}$ is the supporting force generated by the solid coal side, $\mathrm{kN}$; $F_{m}$ is the support resistance required by the roadway, $\mathrm{kN} ; F_{g}$ is the supporting force produced by rock blocks in goaf, $\mathrm{kN}$; $x_{0}$ is the range of plastic zone on the solid coal side, $\mathrm{m} ; b$ is the width of roadway, $m$; $e$ is the action range of rock supporting force in goaf, $\mathrm{m} ; h$ is the height of coal seam, $\mathrm{m} ; h_{f}$ is the height of the immediate roof, $\mathrm{m} ; h_{d}$ is the roof cutting height, $\mathrm{m} ; \beta$ is the roof cutting angle, ${ }^{\circ} ; L_{i}$ is the breaking length of key block $\mathrm{B}, \mathrm{m} ; F_{h}$ is the dead weight of the immediate roof and key block B; $\theta$ is the turning angle of key block $\mathrm{B}, \stackrel{\circ}{;} u_{1}$ is the position of the key block $\mathrm{B}$ contacting the goaf; $u_{3}$ is the final sinking position of the key block.

\subsection{Mechanical Model of Key Block}

3.1.1. Limited Breaking Length Li of the Rock Stratum of Key Block B. Fracture line theory indicates that, in the process of the basic roof fracture when the goaf passes through the first collapse, the length $L_{i}$ of the key block fracture is shown in the following equation:

$$
L_{i}=l\left(-\frac{l}{2 S}+\sqrt{\frac{l^{2}}{4 S^{2}}+\frac{3}{4}}\right) .
$$

Meanwhile, when the goaf passes through the interval of periodic weighting, the breaking length $L_{i}$ of the key block is shown in the following equation:

$$
\begin{aligned}
L_{\mathrm{i}} & =1\left(-\frac{l}{S}+\sqrt{\frac{l^{2}}{S^{2}}+\frac{3}{2}}\right), \\
L_{d} & =L_{i} \cos \theta,
\end{aligned}
$$

where $S$ is the length of working face, $\mathrm{m}$.

3.1.2. Support Force $F_{g}$ of Waste Rock in Goaf to Key Block. When the key block B contacts with the rock block in the goaf after the roadway is formed, the subsidence of the sinking end of the key block $\mathrm{B}$ is $u_{0}$, as shown in the following formula:

$$
u_{0}=h-\left(K_{\mathrm{s}}-1\right) h_{\mathrm{f}},
$$

where $h$ is the mining height, $\mathrm{m}$, and $K_{s}$ is the coefficient of roof rock fragmentation expansion.

At this time, the position coordinate $u_{1}$ of the subsidence end of the key block contacting the rock block in the goaf is shown in the following equation:

$$
u_{1}=\frac{u_{0}}{\tan \theta} .
$$

Key block B continues to sink under the action of overburden load and its gravity, and the collapsed rock blocks in the goaf are continuously compacted. The supporting force of goaf rock blocks to key blocks increases with the continuous compaction of goaf rock blocks. The equilibrium state is formed under the joint actions of overlying load, solid coal support force, roadway support resistance, and support force of rock block in goaf with the cancelation of the subsidence state of key blocks. Thus, the sinking distance $u_{2}$ of key block $\mathrm{B}$ is shown in the following equation:

$$
u_{2}=h-\left(K_{c}-1\right) h_{f},
$$

where the coordinate position of the key block contacting the waste rock is $u_{3}$, as shown in the following equation:

$$
u_{3}=\frac{u_{2}}{\tan \theta}
$$

where $K_{c}$ is the residual crushing expansion coefficient of collapsed rock mass after compaction, which can be determined by simulation tests or field measurements.

In the process of key block sinking, the overall compression amount $\Delta u$ of caving rock block under the action of the key block due to the continuing compaction of the waste rock in goaf is shown in the following equation:

$$
\Delta u=u_{3}-u_{1} .
$$

In the entire key block from the subsidence activation state to the stable structure of the hinged load-bearing structure, the supporting force [24] $f_{g}$ per unit area of the caving rock block in the goaf is shown in the following equation: 


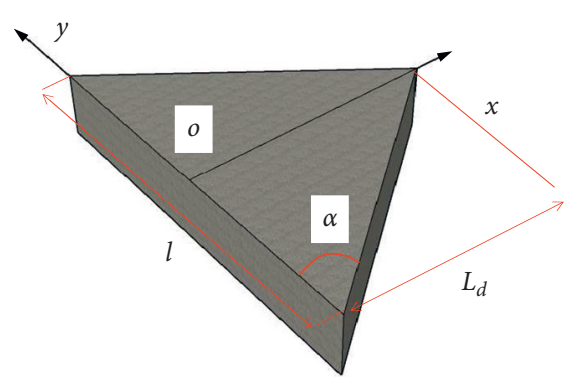

Figure 1: Mechanical model of key block B in roadway retaining.

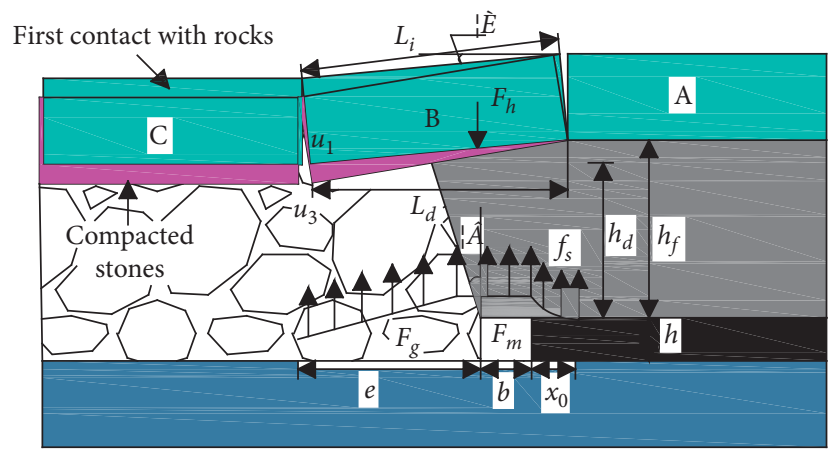

FIgURE 2: Mechanical structure model of key block.

$$
f_{g}=K_{g} \Delta u
$$

where $K_{g}$ is the support coefficient of caving waste rock, $\mathrm{MPa} / \mathrm{m}$.

The supporting force $F_{g}$ of the entire waste rock in the goaf to the key block is then presented in the equation as follows:

$$
F_{g}=\int_{u_{3}}^{e} \frac{f_{g}\left[-2\left(x-L_{i}\right)\right]}{\tan \alpha \cos \theta} \mathrm{dx} .
$$

Among them,

$$
\mathrm{a}=\frac{L_{i}-x_{0}-\mathrm{b}-h_{\mathrm{d}} \tan \beta}{\cos \theta} .
$$

The expression of width $x_{0}$ of the limit equilibrium zone of the coal body in the roadway is shown in the equation as follows:

$$
x_{0}=\frac{h A}{2 \tan \delta} \ln \left(\frac{k \gamma H+\left(c_{0} / \tan \delta\right)}{\left(c_{0} / \tan \delta\right)+\left(p_{x} / A\right)}\right),
$$

where $A$ is the lateral pressure coefficient; $p_{x}$ is the support strength of coal side, $\mathrm{MPa} ; H$ is the buried depth of roadway, $\mathrm{m} ; c_{0}$ is the bonding strength of coal and rock mass, $\mathrm{MPa} ; \delta$ is the internal friction angle of coal body, ${ }^{\circ} ; \gamma$ is the average density of overlying strata $\mathrm{KN} / \mathrm{m}^{3} ; k$ is the stress concentration factor; and $h$ is the height of roadway, $\mathrm{m}$.

$$
\alpha=\arctan \left(\frac{2 L_{i}}{l}\right)
$$

3.1.3. Support Force $f_{s}$ of Coal Side Wall beside Roadway. The breaking position of key block B is at the elastic-plastic interface of the solid coal side of the retained roadway. The supporting force $f_{s}$ of the solid coal on the key block is shown in the equation as follows:

$$
f_{s}=\left(\frac{c_{0}}{\tan \varphi_{0}}+\frac{p_{x}}{A}\right) e^{\frac{2 x \tan \varphi_{0}}{h A}}-\frac{c_{0}}{\tan \varphi_{0}},
$$

where $\varphi_{0}$ is the internal friction angle of the top and bottom slate interface, ${ }^{\circ}$.

3.1.4. Load $F_{h}$ of Key Block B and Overlying Strata. The load of the immediate roof and the key block jointly acts on the roadway roof, as shown in the following formula:

$$
F_{\mathrm{h}}=\frac{\left(x_{0}+b\right)^{2} \gamma H_{i}}{\tan \alpha},
$$

where $H_{i}$ is the thickness of the immediate roof and key layer, $\mathrm{m}$.

3.1.5. Roadway Support Resistance $F_{m}$. The effective loadbearing structure is formed by the anchoring range of the bolt, and the integrity of the roof is increased. The suspension effect of the constant resistance anchor cable stabilizes the roof of the retained roadway. The support resistance of the bolt and the anchor cable to the roadway is $F_{m}$.

The torque produced by $F_{z}, F_{g}, f_{s}$, and $F_{m}$ on the rotation of key block B is as follows:

$$
\left\{\begin{array}{l}
R_{h}=\frac{F_{h}\left(x_{0}+b\right)}{3} \\
R_{g}=\int_{\left(u_{0} / \tan \theta\right)}^{\left(\left(L_{i}-x_{0}-b-h_{\mathrm{d}} \tan \beta\right) / \cos \theta\right)} f_{g} \frac{\left[-2\left(x-L_{i}\right)\right]}{\tan \alpha \cos \theta} x \mathrm{~d} x, \\
R_{s}=\int_{x_{0}}^{x_{0}+b} f_{s} \frac{\left[-2\left(x-L_{i}\right)\right]}{\tan \alpha \cos \theta} x \mathrm{~d} x, \\
R_{m}=\frac{F_{m}\left(x_{0}+b\right)}{2} .
\end{array}\right.
$$


According to the relation $\sum M=0$, the following equation is obtained:

$$
F_{m}=\frac{2 F_{h}\left(x_{0}+b\right)-6 G\left[D E L_{\mathrm{i}} M+D E H-2 D E^{2} J+F N+\mathrm{f}_{g} P+6 M_{0}\right]}{3\left(x_{0}+b\right)} .
$$

The fixed end of the immediate roof is assumed to be a fixed boundary condition as follows:

$$
M_{0}=\frac{1}{6} \sigma_{t} h_{f}^{2} l
$$

where $\sigma_{t}$ is the tensile strength of the key block, MPa. Among them,

$$
\left\{\begin{array}{l}
D=\frac{c_{0}}{\tan \varphi_{0}}+\frac{p_{x}}{A}, \\
E=\frac{h A}{2 \tan \varphi_{0}}, \\
F=\frac{c_{0}}{\tan \varphi_{0}}, \\
G=\frac{2}{\tan \alpha \cos \theta}, \\
H=\left(x_{0}+b\right)^{2} e^{\left(\left(x_{0}+b\right) / E\right)}-x_{0}^{2} e^{\left(x_{0} / E\right)}, \\
J=\left(x_{0}+b\right) e^{\left(\left(x_{0}+b\right) / E\right)}-e^{\left(x_{0} / E\right)} x_{0}-E e^{\left(\left(x_{0}+b\right) / E\right)}+E e^{\left(x_{0} / E\right)} \\
M=e^{\left(\left(x_{0}+b\right) / E\right)}\left(x_{0}+b\right)-e^{\left(x_{0} / E\right)} x_{0}+E e^{\left(\left(x_{0}+b\right) / E\right)}-E e^{\left(x_{0} / E\right)} \\
N=\frac{L_{i}}{2}\left[\left(x_{0}+b\right)^{2}-x_{0}^{2}\right]+\frac{1}{3}\left[x_{0}^{3}-\left(x_{0}^{2}+a^{2}\right)+\frac{1}{3}\left(a^{3}-u_{1}^{3}\right) .\right. \\
P
\end{array}\right.
$$

\subsection{Analysis of the Influence Factors of Roof Support Resistance} of Retaining Roadway. The analysis is conducted to realize the technology of roof cutting and pressure relief and gobside entry retaining in the Hengyuan coal mine. Combined with the actual geological conditions, the results show that the internal friction angle of the interface between the top and bottom slate is $\varphi_{0}=38^{\circ}$, and the average density of overlying strata is $\gamma=24 \mathrm{kn} / \mathrm{m}^{3}$. The results also reveal the following: coefficient of lateral pressure $A=0.41$; bond strength of coal and rock mass $c_{0}=0.84 \mathrm{MPa}$; support strength of coal wall $p_{x}=0.2 \mathrm{MPa}$; basic roof interval of periodic weighting $l=30 \mathrm{~m}$; working face length $S=185 \mathrm{~m}$; key block rotation angle $\theta=5^{\circ}$; working face buried depth $H=650 \mathrm{~m}$; coal body friction angle $\delta=26^{\circ}$; mining height $h=3 \mathrm{~m}$; stress concentration factor $k=1.6$ tensile strength of the key block $\sigma_{t}=1.68 \mathrm{MPa}$. The results also show that the crushing expansion coefficient of roof rock is $K_{s}=1.2$, the residual coefficient of crushing expansion after compaction of rock block in caving goaf is $K_{c}=0$, and the height of the immediate roof is $h_{f}=10 \mathrm{~m}$. The relationship between the roof cutting angle and height and the roof support resistance is shown in Figure 3.

Figure 3 shows the relationship between the roof cutting angle and height and the support resistance. Figure 3(a) displays that the support resistance required by roadway support increases with the roof cutting height. The supporting resistance of the roadway correspondingly increases with the roof cutting height due to the self-weight of the overlying strata. The key layer structure is the main carrier to bear the overlying load when the roof cutting height reaches the position near the load-bearing structure of the key layer, and the support resistance required by the roof retaining slowly increases.

Figure 3(b) shows that the support resistance of the roadway roof is related to the roof cutting angle in stage I. The support resistance of retaining roadway roof also increases with the roof cutting angle. The large exposed area of the short cantilever beam of the roof indicates the large load on the roadway roof. The key block $\mathrm{C}$ acts on the triangular area of the roadway hanging roof, which further intensifies the rotation of the key block B. The change trend enters the second stage with the increase in roof cutting angle, and the support resistance of retaining roadway slowly increases. The goaf roof is between cutoff and no cutoff during this period, the cantilever beam structure of the left roadway is incompletely cut off, and the rock blocks in the goaf provide part of the support force. Thus, the key block is in the dynamic process from contacting rock block to full compaction, which slowly raises the support resistance of roadway retaining. The change trend will enter into stage III with the increase in the roof cutting angle. The relationship between roadway and goaf roofs is not cut off. The goaf roof stress is transmitted to the retained roadway roof through the long cantilever beam structure, which exponentially increases the support resistance of the retained roadway roof.

\section{Determination of Key Parameters of Roof Cutting Seam in Retained Roadways}

4.1. Analysis of the Roof Cut Height of the Roadway Roof. Determining the reasonable cutting parameters first based on the influence of the cutting parameters of the roadway roof on the support resistance is necessary. In actual engineering conditions, the connection between the basic and goaf roofs cannot be cut off when the roof cutting height is small. The sinking and rotation of key blocks still have a substantial impact on the roadway roof. After the mined-out area collapses in a short time, there are cracks between the gangue. A tendency to continue rotating movements in the roof slab of the reserved lane also exists. The large structure of the roof rock layer of the roadway is destroyed when the roof cutting height is large, and the overlying load acts on the roadway roof, making it difficult to support the roadway roof. 


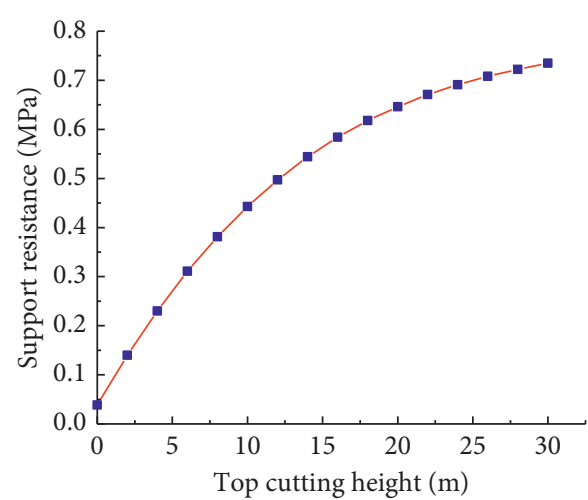

(a)

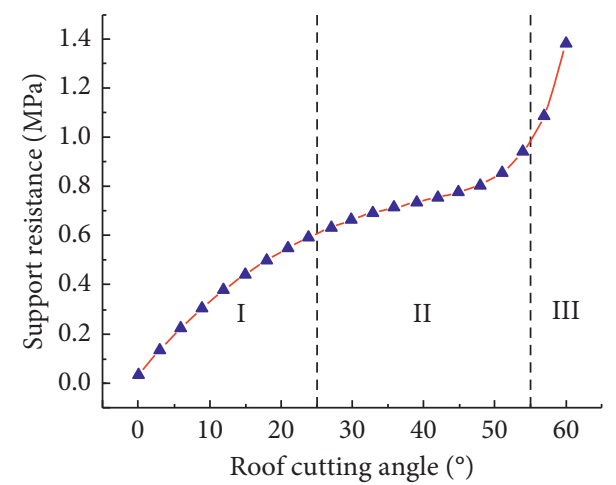

(b)

FIGURE 3: Distribution curve of roof support resistance under different roof cutting conditions. (a) Relationship between roof cutting height and support resistance. (b) Relationship between roof cutting angle and support resistance.

Therefore, the height of the cutting seam should be larger than the sum of the height of the basic and the immediate roofs. Thus, the roadway roof cuts off the connection with the goaf roof.

$$
H_{k}=H_{z}+H_{j}
$$

where $H_{k}$ is the top cutting height, $\mathrm{m} ; H_{z}$ is the height of the immediate roof, $\mathrm{m}$; and $H_{j}$ is the height of the basic roof, $\mathrm{m}$.

After the collapse of the rock stratum, the goaf will be filled with rock blocks through its fragmentation and swelling, which will reduce the collapsed height of the overlying strata in the goaf. Therefore, the cutting joint height of the retained roadway roof is as follows:

$$
H_{\mathrm{k}}=\sum_{\mathrm{i}=1}^{\mathrm{n}} H_{\mathrm{i}}=\frac{\mathrm{h}}{K_{p}-1}
$$

where $H_{i}$ is the thickness of layer $i$ and $K_{p}$ is the average breaking up coefficient.

$$
K_{p}=\frac{\sum_{i=1}^{n} K_{i} H_{i}}{\sum_{i=1}^{n} H_{i}}
$$

where $K_{i}$ is the breaking up coefficient of layer $i . K_{p}$ is generally 1.3 and 1.5 .

When $H_{\mathrm{z}}+H_{\mathrm{j}} \geq\left(\mathrm{h} /\left(K_{\mathrm{p}}-1\right)\right)$ is used,the cutting height is calculated as shown in equation (19):

When $H_{\mathrm{z}}+H_{\mathrm{j}} \leq\left(\mathrm{h} /\left(K_{\mathrm{p}}-1\right)\right)$ is used, the cutting height is calculated as shown in equation (20):

The actual geological conditions of the Hengyuan coal mine reveal that the immediate roof height of roadway retaining working face is $2.25-4.8 \mathrm{~m}$, the basic roof height is $2.25-4.8 \mathrm{~m}$, the thickness of coal seam is $2.8 \mathrm{~m}$, and the average breaking up coefficient $K_{p}$ of the rock layer is 1.3 . Therefore, the roof cutting height of II 632 working face in the Hengyuan coal mine is $8-9.3 \mathrm{~m}$.

\subsection{Analysis of Roof Cutting Angle of Retained Roadway Roof.} The side rock mass of the goaf cannot slide down along the cutting seam line when the roof cutting angle is small due to the influence of static friction between rock masses.
Moreover, the goaf can still transfer force to the roadway roof, driving the rotation, and sinking of the rock mass of the retained roadway roof. The impact energy produced by blasting causes remarkable damage to the roadway roof integrity and weakens the anchoring bolt effect on the retained roadway roof. If the roof cutting angle is considerably large, then cutting the seam line cannot cut off the path of roof stress transmission, and roadway retaining easily causes damage.

FLAC3D numerical simulation software is used to analyze the cutting parameters to verify the size and rationality of the key parameters of roof cutting.

4.3. Establishment of the Numerical Model. FLAC3D numerical simulation software is used for simulation analysis to obtain the reasonable value of roof cutting angle and height in the roof cutting and pressure relief technology of the haulage drift in the Hengyuan coal mine. A numerical model with a length and width of $300 \mathrm{~m} \times 73.1 \mathrm{~m}$ is established following actual engineering geological conditions of II 632 fully mechanized working face in Hengyuan coal mine, as shown in Figure 4. The original rock stress is $16.25 \mathrm{MPa}$, and its displacement is constrained around the model. The right goaf is filled with the elastic body model. The rock mechanical parameters are shown in Table 1.

4.4. Analysis of Numerical Simulation Results of Roof Cutting Height. Figure 5 shows the influence of simulated roof cutting height of 6,8 , and $10 \mathrm{~m}$ on the surrounding rock stress of cut retained roadway roof. A comprehensive comparison can also be obtained. When the roof cutting height is $6 \mathrm{~m}$, the stress concentration in the solid coal side of the retained roadway is $24.98 \mathrm{MPa}$, the peak value range of the stress concentration in the solid coal side of the retained roadway is large, and a certain pressure relief area exists around the retained roadway roof. When the roof cutting height is $8 \mathrm{~m}$, the peak value of the stress concentration at the solid coal side of the roadway is $23.89 \mathrm{MPa}$, which is far away from the retained roadway surface, and the pressure relief range around the roadway roof is further increased. When 


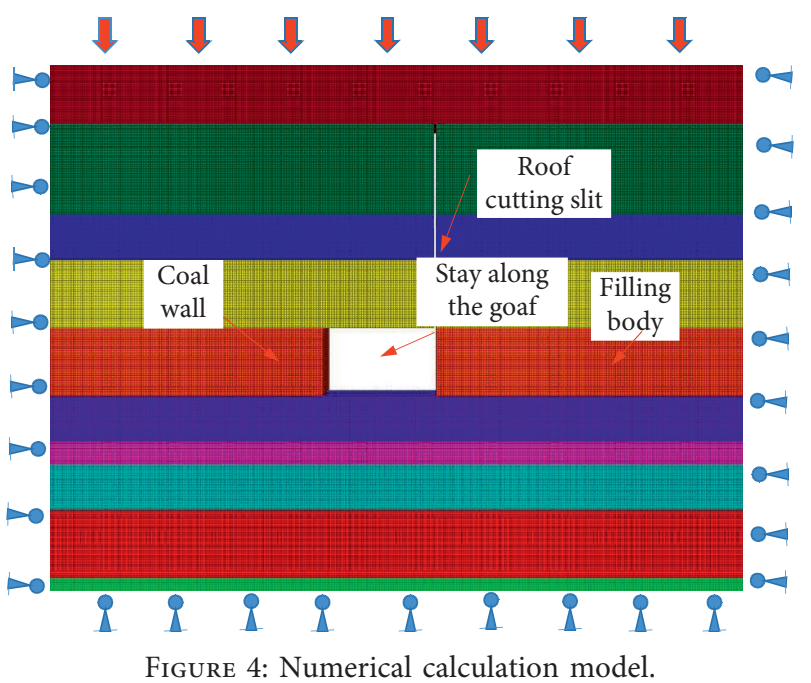

TABLE 1: Rock mechanical parameters.

\begin{tabular}{|c|c|c|c|c|c|c|}
\hline Lithology & $\begin{array}{l}\text { Bulk density } \\
\left(\mathrm{kg} / \mathrm{m}^{3}\right)\end{array}$ & $\begin{array}{l}\text { Bulk modulus } \\
\qquad(\mathrm{GPa})\end{array}$ & $\begin{array}{l}\text { Shear modulus } \\
(\mathrm{GPa})\end{array}$ & $\begin{array}{c}\text { Internal friction } \\
\text { angle }\left({ }^{\circ}\right)\end{array}$ & $\begin{array}{c}\text { Cohesion } \\
(\mathrm{MPa})\end{array}$ & $\begin{array}{c}\text { Tensile strength } \\
(\mathrm{MPa})\end{array}$ \\
\hline $\begin{array}{l}\text { Sandy } \\
\text { mudstone }\end{array}$ & 2652 & 2.54 & 1.38 & 30 & 1.3 & 0.43 \\
\hline Siltstone & 2610 & 10.9 & 8.58 & 30 & 17.2 & 5.75 \\
\hline Mudstone & 2570 & 7.87 & 6.40 & 38 & 2.07 & 1.68 \\
\hline Fine sandstone & 2630 & 6.68 & 1.40 & 28 & 1.66 & 1.70 \\
\hline Mudstone & 2570 & 7.87 & 6.4 & 38 & 2.07 & 1.68 \\
\hline Coal & 1360 & 1.9 & 0.93 & 26 & 0.84 & 0.28 \\
\hline Mudstone & 2570 & 7.87 & 6.4 & 38 & 2.07 & 1.68 \\
\hline Siltstone & 2610 & 10.9 & 8.58 & 30 & 17.2 & 5.75 \\
\hline Mudstone & 2570 & 7.87 & 6.4 & 38 & 2.07 & 1.68 \\
\hline
\end{tabular}

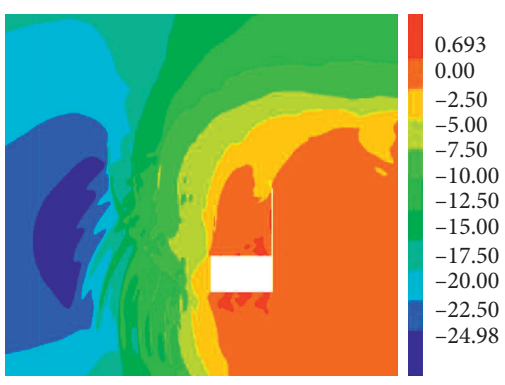

(a)

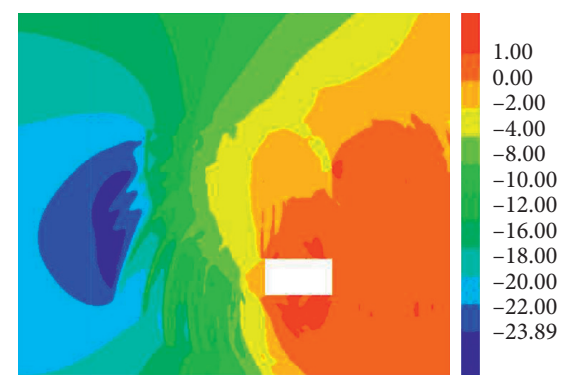

(b)

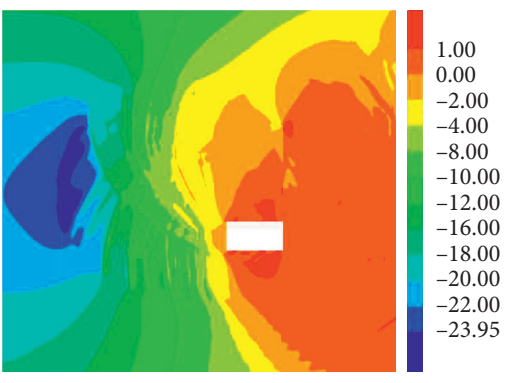

(c)

Figure 5: Vertical stress distribution under different roof cutting heights (MPa). (a) Roof cutting height of $6 \mathrm{~m}$. (b) Roof cutting height of $8 \mathrm{~m}$. (c) Roof cutting height of $10 \mathrm{~m}$.

the roof cutting height is $10 \mathrm{~m}$, the peak value of the stress concentration at the solid coal side of the retained roadway is 23.95 MPa. No significant difference is observed between the stress concentration range of the retained roadway solid coal side and the roof cutting height of $6 \mathrm{~m}$, and the pressure relief range of the retained roadway roof is slightly larger than that of the roof cutting height of $8 \mathrm{~m}$. These findings are obtained from the above analysis. When the roof cutting height is $8 \mathrm{~m}$, the peak stress concentration is smaller than that when the roof cutting height is 6 and $10 \mathrm{~m}$. When the stress concentration range is less than the roof cutting height of $6 \mathrm{~m}$, the pressure relief area of the retained roadway roof increases with the roof cutting height. Therefore, the pressure relief thickness of the retained roadway roof increases with the roof cutting height, and the required support resistance also rises.

Figure 6 shows the following results. The roof subsidence of the retained roadway is $1000 \mathrm{~mm}$ when the roof cutting height is $6 \mathrm{~m}$; thus, meeting the use requirements of the retained roadway is difficult. The subsidence of the retained 


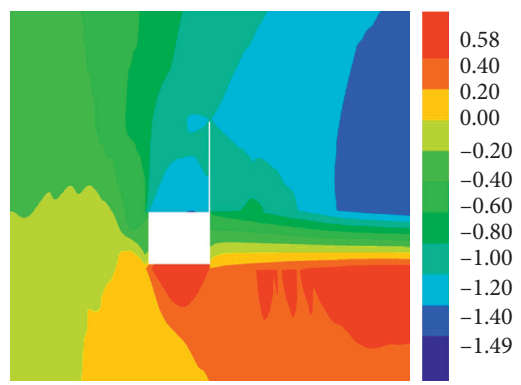

(a)

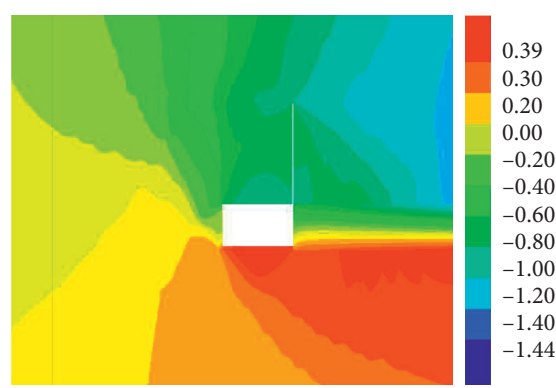

(b)

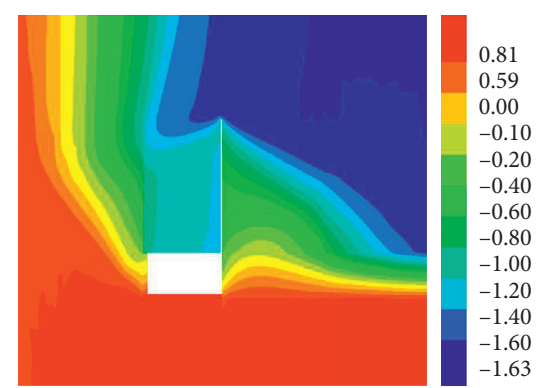

(c)

FIGURE 6: Vertical displacement distribution under different roof cutting heights $\mathrm{m}$. (a) Roof cutting height of $6 \mathrm{~m}$. (b) Roof cutting height of $8 \mathrm{~m}$. (c) Roof cutting height of $10 \mathrm{~m}$.

roadway roof is $400 \mathrm{~mm}$ when the cutting height is $8 \mathrm{~m}$, and the roof subsidence of the retained roadway is small. The roof subsidence of the retained roadway is $1000 \mathrm{~mm}$ when the roof cutting height is $10 \mathrm{~m}$.

The comprehensive comparison shows the following: when the roof cutting height is $8 \mathrm{~m}$, the roof strata in goaf can be completely cut off, which weakens the influence of stress transmission on the roadway roof. Moreover, the stress in solid coal is small, and the stress concentration value is far away from the roadway. The roof stress is in a controllable range, which is conducive to the stability of the roadway roof plate. When the roof cutting height is $6 \mathrm{~m}$, the influence of the basic roof on the retained roadway roof cannot be cut off. The rotation of the basic roof has a considerable influence on the roof. The subsidence of the retained roadway roof is $1000 \mathrm{~mm}$, and the peak value of the stress concentration coefficient of the solid coal side is large. When the roof cutting height is $8 \mathrm{~m}$, the influence of the basic roof on the roadway roof can be completely cut off, the influence of the stress transfer on the retained roadway roof is weakened, and the influence of the basic roof rotation on the retained roadway roof is reduced. Moreover, the peak stress concentration range is reduced, and the support resistance of the retained roadway roof is less than $10 \mathrm{~m}$ of the roof cutting height. When the roof cutting height is $10 \mathrm{~m}$, the seam line can cut off the connection between the immediate and retained roadway roofs. However, the pressure relief area of the retained roadway roof is large, the support resistance required by the retained roadway roof increases, and the peak value of the stress concentration at the solid coal side is large. This condition is not conducive to the integrity of the surrounding rock of the retained roadway. Considering the workload of drilling depth and economic benefits, maintaining the roof cutting height of $8 \mathrm{~m}$ is reasonable.

\subsection{Analysis of Numerical Simulation Results of Roof Cutting} Angle. Three kinds of roof cutting models with roof cutting angles of $10^{\circ}, 15^{\circ}$, and $20^{\circ}$ are constructed on the basis of the above analysis, and the stress and displacement changes of gob-side entry retaining under different roof cutting angles are analyzed. The numerical simulation results are shown in Figures 7 and 8.
Figure 7 shows the following results. When the roof cutting angle is $10^{\circ}$, the peak value of the concentrated stress at the solid coal side of the roadway is $21.26 \mathrm{MPa}$, the stress concentration area of the solid coal side of the roadway is relatively small, and the pressure relief area appears on the retained roadway roof. When the roof cutting angle is $15^{\circ}$, the peak value of the concentrated stress at the solid coal side of the retained roadway is $19.54 \mathrm{MPa}$, and the range of the pressure relief area of the retained roadway roof is relatively increased. When the roof cutting angle is $20^{\circ}$, the peak value of stress concentration at the solid coal side of the roadway is 21.54 MPa, and the pressure relief area of the retained roadway roof is further increased. Based on the above analysis, the following results are presented. When the roof cutting angle is $10^{\circ}$, the sliding down of the basic roof rock block along the cutting seam surface is difficult, and the influence of the goaf roof on the retained roadway roof cannot be cut off. When the roof cutting angle is $15^{\circ}$, the basic roof can slide down along the cutting surface, cut off the connection between the goaf and retained roadway roofs, and increase the pressure relief range of the retained roadway roof. When the roof cutting angle is $20^{\circ}$, although the connection between the goaf and retained roadway roofs is cut off, the increase in the roof cutting angle raises the cantilever beam length of the retained roadway roof and the stress concentration value of the retained roadway solid coal side.

As shown in Figure 8, the subsidence value of the retained roadway roof is $400 \mathrm{~mm}$ when the roof cutting angle is $10^{\circ}$. Therefore, the connection between the goaf and retained roadway roofs cannot be cut off. When the roof cutting angle is $15^{\circ}$, the subsidence value of the retained roadway roof is $100 \mathrm{~mm}$, which can cut off the connection between the goaf and retained roadway roofs and reduce the bending subsidence of the retained roadway roof. When the roof cutting angle is $20^{\circ}$, the cantilever beam length is increased with the roof cutting angle; therefore, the subsidence value of the roof is $400 \mathrm{~mm}$.

Overall, the goaf roof cannot slide along the cutting seam line when the roof cutting angle is $10^{\circ}$ despite the small pressure relief range of the retained roadway roof. Therefore, cutting off the connection between the goaf and retained roadway roofs is difficult. The pressure relief range of the retained roadway roof is relatively large when the roof 


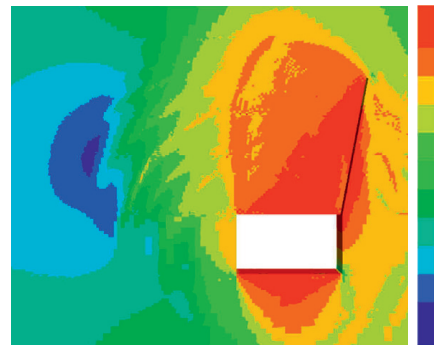

(a)

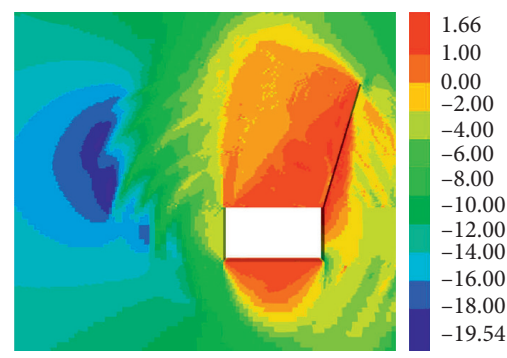

(b)

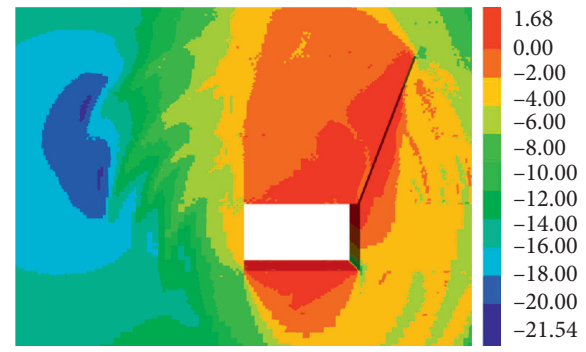

(c)

Figure 7: Vertical stress distribution under different roof cutting angles (MPa). (a) Roof cutting angle is $10^{\circ}$. (b) Roof cutting angle is $15^{\circ}$. (c) Roof cutting angle is $20^{\circ}$.

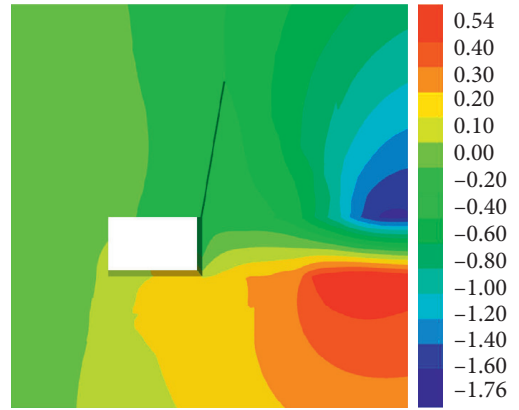

(a)

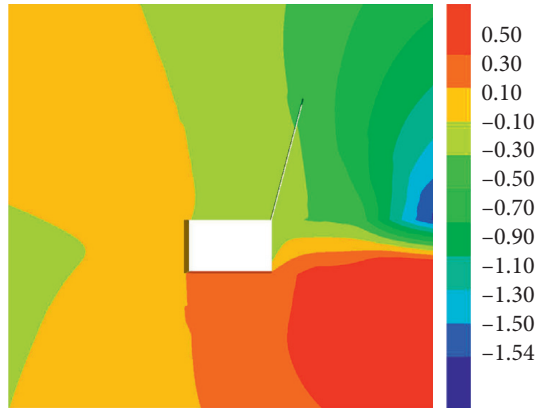

(b)

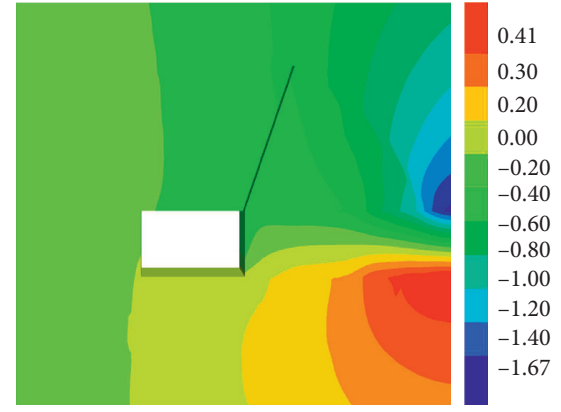

(c)

Figure 8: Vertical displacement distribution of different roof cutting heights (m). (a) Roof cutting angle is $10^{\circ}$. (b) Roof cutting angle is $15^{\circ}$. (c) Roof cutting angle is $20^{\circ}$.

cutting angle is $15^{\circ}$, which can cut off the stress transmission path of the roof plate. The pressure relief range of the retained roadway roof is large when the roof cutting angle is $20^{\circ}$, and the support required by the retaining roof increases. The increase in the roof cutting angle raises the length of the cantilever beam and the subsidence of the retained roadway roof. Considering the damaging effect of blast hole explosion on the retained roadway roof, the support resistance required for the retained roadway roof should be small and the roof cutting angle should be $15^{\circ}$ to reduce the overall damage of blasting to the retained roadway roof and simultaneously facilitate sliding down of the goaf slide roof along the cutting seam line.

\section{Industrial Practice}

5.1. Project Overview. The length distance along the coal seam strike of II 632 working face in the Hengyuan coal mine is $1725.3 \mathrm{~m}$, and the distance between haulage drift and ground is -637 to $-778 \mathrm{~m}$. The retaining roadway technology along the goaf to roof cutting and pressure releasing is adopted in the haulage drift. Therefore, the Yunshun roadway can be used as the return air roadway of the next mining face. The direct roof of the coal mining face is dark gray mudstone with a thickness of $2.25-4 \mathrm{~m}$, dark gray to gray-black, slightly silty, and has an average of $3.13 \mathrm{~m}$. Two coal lines with a thickness of approximately $0.1 \mathrm{~m}$ are often developed in the middle of the coal seam. The composite roof is formed when the lower coal line is close to the No. 6 coal seam, and the roof easily falls off. The immediate roof is gray to light gray fine sandstone with a thickness of $2.5-4.8 \mathrm{~m}$. This roof is gray with developed fractures, with siltstone and mudstone local inclusions, and calcite filling.

The cross-sectional shape of II 632 haulage drift is distance shaped, as shown in Figure 9. The length $\times$ height is $5.2 \mathrm{~m} \times 3 \mathrm{~m}$, the roof is mainly mudstone and fine sandstone, and the floor is mainly mudstone, which belongs to the combination of the soft top and hard bottom. According to the principle of roof and floor coordinated support, the bolt mesh-cable combined support method is adopted for retaining roadway roof to ensure that the retained roadway can be used safely in the primary and secondary mining processes.

5.2. Design of Support Parameters for Cutting Roof and Retaining Roadway. The analysis of numerical simulation results shows that the roof cutting angle of the II 632 haulage drift in the Hengyuan coal mine is $15^{\circ}$ and the roof cutting height is $8 \mathrm{~m}$. The theoretical calculation reveals that the support resistance of retaining the roadway roof is $0.38 \mathrm{MPa}$. At present, the constant resistance anchor cable with a diameter of $21.8 \mathrm{~mm} \times 9500 \mathrm{~mm}$ is adopted, and the constant resistance anchor cable is connected by a steel ladder beam 


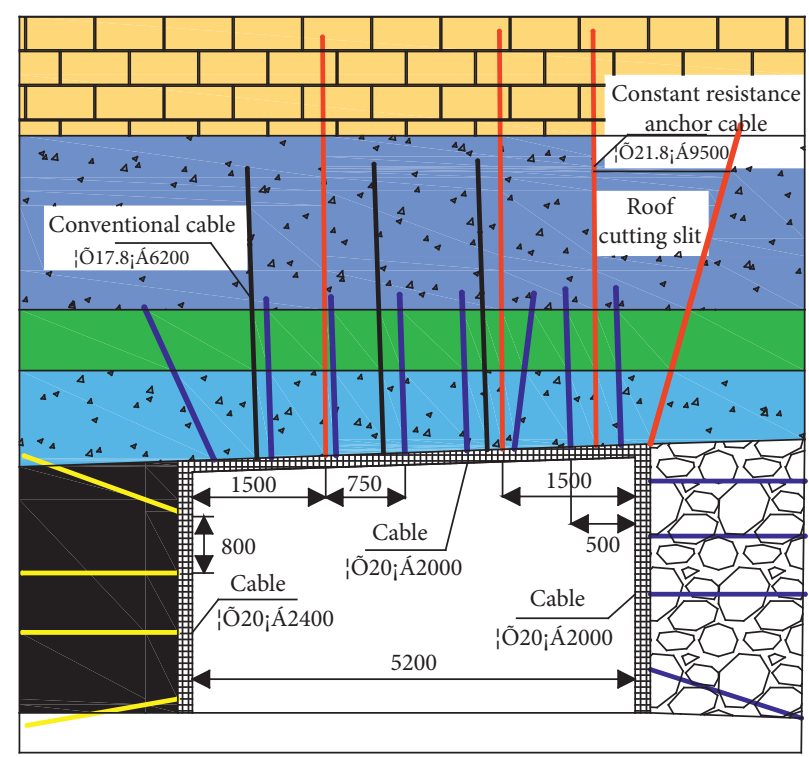

FIgURE 9: Support mode of II 632 haulage drift.

structure. The length of the first row of the constant resistance anchor cable is close to the cutting line, which is $500 \mathrm{~mm}$ away from the roadway side, and the row spacing is $1000 \mathrm{~mm}$; the length of the second row of the constant resistance anchor cable from the retaining side of the roadway is $1500 \mathrm{~mm}$, and the row spacing is $1600 \mathrm{~mm}$; the length of the third row of the constant resistance anchor cable from the cable side is $1500 \mathrm{~mm}$, the row distance is $3200 \mathrm{~mm}$, and the pretension of the constant resistance anchor cable is larger than $25 \mathrm{t}$. The specification of the common anchor cable is $\varphi 17.8 \times 6200 \mathrm{~mm}$, and the spacing between rows is $\varphi 1500 \times 2000 \mathrm{~mm}$; the specification of the roof bolt is $\varphi 20 \times 2000 \mathrm{~mm}$, and the row spacing between anchor bolts is $\varphi 750 \times 800 \mathrm{~mm}$; the specification of the side anchor is $\varphi 24 \times 2000 \mathrm{~mm}$, and the spacing between rows is $\varphi$ $800 \times 800 \mathrm{~mm}$. The combined support method provided a $0.6 \mathrm{MPa}$ support resistance of the roof as indicated in Reference [25], and the bolt mesh cable support layout of II 632 haulage drift is shown in Figure 9.

5.3. Analysis of Roadway Retaining Effect and Field Monitoring Results. The above research determined the roof cutting height and angle of the retained roadway, and an effective support method is applied to the II 632 haulage drift in the Hengyuan coal mine. The roof of the goaf rapidly collapses after the advancement of the working face, and the caving rock blocks quickly fill the goaf. The roof of the retained roadway is immediately supported; thus, the overall deformation of the roadway side is small. The effect of roadway retaining is shown in Figure 10.
The borehole peeping equipment is used to test the crack development of the roadway roof at the middle roof of roadway retaining to meet the requirements of the next mining face in the process of the roadway retaining, as shown in Figure 11.

Figure 12 shows that the distance from the hole on the roof surface is $2.2 \mathrm{~m}$ during the observation process. The roof rock is relatively broken, and the fracture extends longitudinally. The length of the hole from the roof surface of the reserved roadway is $4.1 \mathrm{~m}$, and the aperture is relatively complete. Only a small part of the cracks is developed, and the integrity of the roadway is good. The anchor cable at the roof effectively controls the roof deformation.

Five observation stations are arranged in the haulage drift according to the deformation of the $500 \mathrm{~m}$ long gobside entry retaining roadway of the II 632 haulage drift to observe the roadway deformation continuously through the summary and processing of the monitoring data, as shown in Figure 13.

The deformation monitoring data indicate that the surrounding rock deformation of roadway within $40 \mathrm{~m}$ ahead of the working face is less than $200 \mathrm{~m}$; when the deformation exceeds $40 \mathrm{~m}$ of the working face, the deformation rate of the roadway surrounding rock approaches $0 \mathrm{~mm}$. The deformation increment of roadway within $0-40 \mathrm{~m}$ of the lagging working face is large after retaining the roadway. The deformation amount of surrounding rock of the retained roadway does not exceed $100 \mathrm{~mm}$ after $40 \mathrm{~m}$ of lagging working face. Therefore, the roadway surrounding rock is effectively controlled by the roadway retaining support mode, which provides a safe basis for the next working face. 


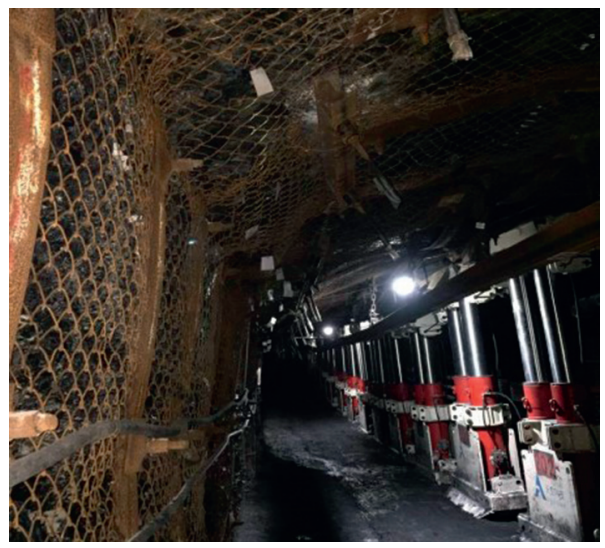

Figure 10: Effect diagram of roadway retaining support.

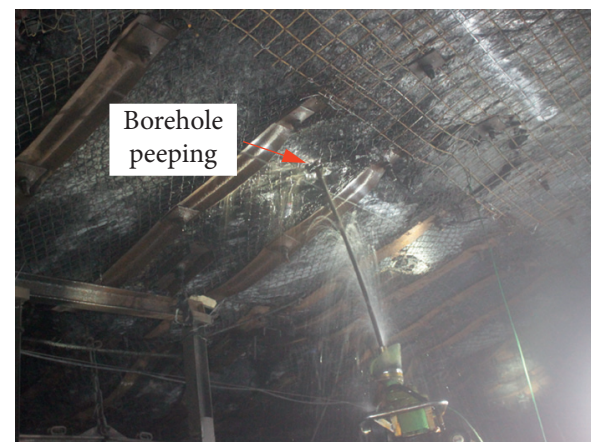

FIGURE 11: Illustration of borehole peeping construction.

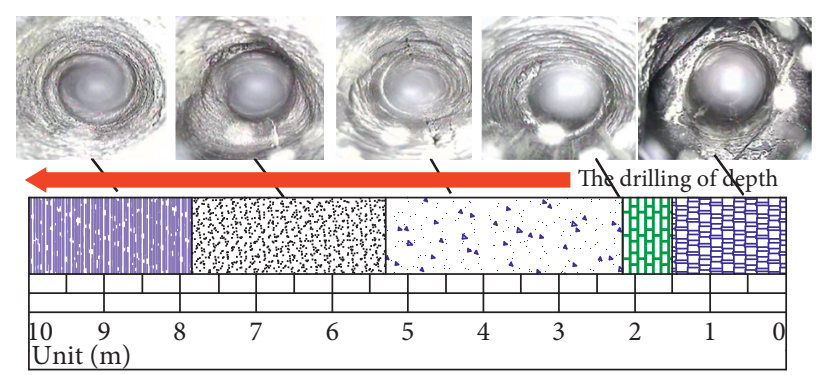

Figure 12: View of roof borehole peeping.

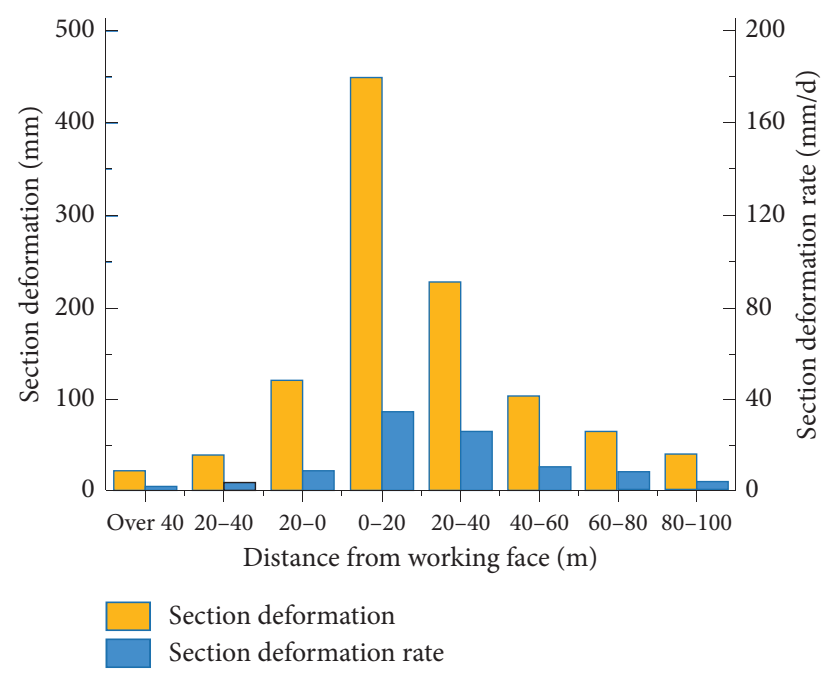

FIGURE 13: Deformation data statistics of surrounding rock of roadway retaining. 


\section{Conclusion}

(1) According to the deformation and movement characteristics of roof structures of gob-side entry retaining, the mechanical key block model of retaining roadway roof is established, and the calculation formula of support resistance under stable roadway roof state is derived. The sensitivity analysis of the related parameters affecting the support resistance is also conducted. The results show that with the increase in roof cutting angle and height, the value of support resistance needed to maintain the stability of retained roadway roofs should also increase correspondingly. The conclusion provides a theoretical basis for the design of roof support parameters of automatic roadway formation by roof cutting and pressure relief.

(2) After theoretical analysis, the numerical analysis models of different roof cutting schemes are established to obtain reasonable roof cutting parameters, and the evolution law of surrounding rock stress and deformation under different roof cutting angles and heights are analyzed. The comprehensive analysis of theoretical calculation and numerical simulation results show that when the roof cutting angle is $15^{\circ}$ and the roof cutting height is $8 \mathrm{~m}$, the goaf side roof can be cut off smoothly by the cutting line. The rotation of key blocks has minimal influence on the retained roadway roof.

(3) Taking the II 632 working face of the Hengyuan coal mine as the engineering background, the support resistance required to maintain the roadway roof stability is calculated on the basis of theoretical analysis and numerical simulation results. Considering the factors such as roof deformation mechanism and supporting material characteristics of cut and pressure relief roadway along gob-side entry retaining, this paper proposed roof support countermeasures for the II 632 haulage drift, adopted the technology of constant resistance and common anchor cables and bolt-combined support, and conducted industrial tests.

(4) Based on the field test data of II 632 haulage roadway in the Hengyuan coal mine, the data show that the roadway retained deformation of the surrounding rock is less than $100 \mathrm{~mm}$ after $40 \mathrm{~m}$ lagging behind the mining face, and the roadway forming effect is good. Through the borehole peeping, the integrity of the retained roadway roof is good. Moreover, the support scheme can effectively control the subsidence of the retained roadway roof and ensure the safety of the next working face.

\section{Data Availability}

The data used to support the findings of this study are included within the article.

\section{Conflicts of Interest}

The authors declare that they have no conflicts of interest.

\section{Acknowledgments}

This work was supported by the National Natural Science Foundation of China (nos. 51574005, 51774010, and 51874002) which are gratefully acknowledged.

\section{References}

[1] Y. L. Tan, F. H. Yu, J. G. Ning, and T. B. Zhao, "Design and construction of entry retaining wall along a gob side under hard roof stratum," International Journal of Rock Mechanics and Mining Sciences, vol. 77, pp. 115-121, 2015.

[2] M. Alber, R. Fritschen, M. Bischoff, and T. Meier, "Rock mechanical investigations of seismic events in a deep longwall coal mine," International Journal of Rock Mechanics and Mining Sciences, vol. 46, no. 2, pp. 408-420, 2009.

[3] R. C. Milici, R. M. Flores, and G. D. Stricker, "Coal resources, reserves and peak coal production in the United States," International Journal of Coal Geology, vol. 113, pp. 109-115, 2013.

[4] S. R. Islavath, D. Deb, and H. Kumar, "Numerical analysis of a longwall mining cycle and development of a composite longwall index," International Journal of Rock Mechanics and Mining Sciences, vol. 89, pp. 43-54, 2016.

[5] X. Ma, M. He, Y. Wang, Y. Zhang, J. Zhang, and Y. Liu, "Study and application of roof cutting pressure releasing technology in retracement channel roof of Halagou 12201 working face," Mathematical Problems in Engineering, vol. 2018, Article ID 6568983, 15 pages, 2018.

[6] Z. Ma, J. Wang, M. He, Y. Gao, J. Hu, and Q. Wang, "Key technologies and application test of an innovative noncoal pillar mining approach: a case study," Energies, vol. 11, no. 10, Article ID 2853, 2018.

[7] H. Manchao, G. Yubing, Y. Jun, and G. Weili, “An innovative approach for gob-side entry retaining in thick coal seam longwall mining," Energies, vol. 10, no. 11, Article ID 1785, 2017.

[8] M. He, X. Ma, and B. Yu, "Analysis of strata behavior process characteristics of gob-side entry retaining with roof cutting and pressure releasing based on composite roof structure," Shock and Vibration, vol. 2019, Article ID 2380342, 12 pages, 2019.

[9] X. G. Ma, M. C. He, J. Wang, Y. Gao, D. Zhu, and Y. Liu, "Mine strata pressure characteristics and mechanisms in gobside entry retention by roof cutting under medium-thick coal seam and compound roof conditions," Energies, vol. 11, no. 10, Article ID 2539, 2018.

[10] Z. Guo, Q. Wang, Z. Li et al., "Surrounding rock control of an innovative gob-side entry retaining with energy-absorbing supporting in deep mining," International Journal of Low Carbon Technologies, vol. 14, no. 1, pp. 23-35, 2019.

[11] Y. Wang, Y. B. Gao, E. Y. Wang et al., "Roof deformation characteristics and preventive techniques using a novel nonpillar mining method of gob-side entry retaining by roof cutting," Energies, vol. 11, no. 3, p. 627, 2018.

[12] J. Yang, H. Y. Wang, Y. J. Wang et al., "Stability analysis of the entry in a new mining approach influenced by roof fracture position," Sustainability, vol. 11, no. 22, Article ID 6349, 2019. 
[13] P. Zhou, Y. Wang, G. Zhu, and Y. Gao, "Comparative analysis of the mine pressure at non-pillar longwall mining by roof cutting and traditional longwall mining," Journal of Geophysics and Engineering, vol. 16, no. 2, pp. 423-438, 2019.

[14] J. Wang, D. Zhu, W. Gong, and M. He, "Physical simulation experiment on the movement of rock strata upon automatic roadway forming by roof cutting and pressure releasing," Chinese Journal of Rock Mechanics and Engineering, vol. 37, no. 11, pp. 2536-2547, 2018.

[15] Z. Zhu, K. Zhang, M. He, and J. Yang, "Surrounding rocks control technology and application of automatically formed roadway in mining without coal pillar and gateroad excavation," Journal of China Coal Society, vol. 43, no. S1, pp. 52-60, 2018.

[16] G. Zhang, M. He, X. Yu, and Z. G. Huang, "Research on the technique of no-pillar mining with gob-side entry formed by advanced roof caving in the protective seam in Baijiao coal mine," Journal of Mining \& Safety Engineering, vol. 28, no. 4, pp. 511-516, 2011.

[17] X. Ma, M. He, J. Sun et al., "Neural network of roof cutting blasting parameters based on mines with different roof conditions," Energies, vol. 11, no. 12, Article ID 3468, 2018.

[18] Q. Wang, B. Jiang, L. Wang, B. Liu, and Y. Wang, "Control mechanism of roof fracture in no-pillar roadways automatically formed by roof cutting and pressure releasing," Arabian Journal of Geosciences, vol. 13, no. 6, 2020.

[19] X. Yang, C. Hu, M. He et al., "Study on presplitting blasting the roof strata of adjacent roadway to control roadway deformation," Shock and Vibration, vol. 2019, Article ID 3174898, 16 pages, 2019.

[20] C. Guo, Y. Yuan, Z. H. U. Cheng et al., "Research on the reasonable parameters of cut roof retaining roadway in fully mechanized mining face with thin direct roof and large mining height," Journal of China Coal Society, vol. 44, no. 7, pp. 1981-1990, 2019.

[21] S. Chen, F. Zhao, H. Wang et al., "Determination of key parameters of gob-side entry retaining by cutting roof and its application to a deep mine," Rock and Soil Mechanics, vol. 40, no. 1, pp. 332-342, 2019.

[22] Y. Li and X. Hua, "Mechanical analysis of the stability of the key blocks of the overlying strata along the gob and determination of the width of the backfill beside the roadway," Rock and Soil Mechanics, vol. 40, no. 4, pp. 1134-1140, 2012.

[23] P. Yang, X. Hua, Y. Li et al., "Backfill horizontal stability analysis of gob-side entry retaining with compound roof in deep mine," Rock and Soil Mechanics, vol. 39, no. 1, pp. $405-411,2018$.

[24] Y. Li, X. Hua, and R. Cai, "Mechanics analysis on the stability of key block in the gob-side entry retaining and engineering application," Journal of Mining \& Safety Engineering, vol. 29, no. 3, pp. 357-364, 2012.

[25] Y. Li, C. Zhao, Z. Liu et al., "The stratification evolution law of surrounding rock bearing layer and the strength analysis of "layer-double arch" bearing structure," Chinese Journal of Rock Mechanics and Engineering, vol. 39, no. 2, pp. 217-227, 2020 . 